\title{
STOWARZYSZENIA BIBLIOTEK KOŚCIELNYCH W POLSCE, WLOSZECH I HISZPANII W ŚWIETLE ICH STATUTÓW
}

\begin{abstract}
Streszczenie
Celem artykułu jest ukazanie zagadnienia Stowarzyszenia Bibliotek Kościelnych w świetle wybranych statutów w aspekcie kanonicznym. W jego pierwszej części przedstawiono kwestię natury, celów i sposobów działania tej instytucji. W drugiej części wskazano na wewnętrzną organizację Stowarzyszenia, trzecią poświęcono jego władzom, a czwartą majątkowi Stowarzyszenia Bibliotek Kościelnych.

Słowa kluczowe: biblioteka; statut; książki; stowarzyszenie bibliotek kościelnych; majątek; biblioteka kościelna
\end{abstract}

\section{Wstęp}

Biblioteki kościelne, które przechowują i udostępniają skarby kultury ludzkiej oraz chrześcijańskiej powstałe na przestrzeni wieków, stanowią niezwykłe bogactwo wiedzy, w którym każda wspólnota, tak świecka, jak i duchowna, ma możność odnalezienia wspomnienia swojej przeszłości. Jednak szczególne zainteresowanie Kościoła bibliotekami kościelnymi spowodowane jest tym, że Ewangelia, którą on przekazuje i strzeże, dała początek historii i kulturze chrześcijańskiej, stając się źródłem niezwykłego rozkwitu myśli religijnej, literackiej, filozoficznej, prawniczej, artystycznej, psychologicznej i pedagogicznej. Przechowywanie książek, zachęcanie do ich czytania i rozpowszechniania jest dla Kościoła działalnością bardzo bliską jego misji ewangelizacyjnej ${ }^{1}$.

* Ks. Jerzy Adamczyk - dr hab. prawa kanonicznego; wykładowca Wyższego Seminarium Duchownego w Radomiu;

e-mail:ksjerzyad@wp.pl

https://orcid.org/0000-0003-1415-73781

${ }^{1}$ Por. Pontificia Commissione per i Beni Culturali della Chiesa, Lettera circolare Le biblioteche ecclesiastiche nella missione della Chiesa (19 marzo 1994), nr 1. 2, w: Enchiridion dei Beni Culturali della Chiesa. Documenti ufficiali della Pontificia Commissione per i Beni Culturali della Chiesa, Bologna 2002, s. 201-219, tekst polski: „Fides. Biuletyn bibliotek kościelnych”, 1-2 (1996) s. 31-46. 
W celu popierania chrześcijańskiej doktryny, ewangelizacji oraz lepszej ochrony i rozpowszechniania swojego dziedzictwa bibliograficznego, usprawniania działalności bibliotek kościelnych osoby fizyczne należące do Kościoła Katolickiego, reprezentujące biblioteki kościelne, dobrowolnie zrzeszają się w Stowarzyszenia Bibliotekarzy Kościelnych o zasięgu krajowym, posiadających swoje statuty.

Refleksje podjęte w niniejszym artykule opierają się na statutach Stowarzyszeń Bibliotek Kościelnych w Polsce, Włoszech i Hiszpanii. Wybrano te właśnie statuty, gdyż są one normami wewnętrznymi dużych i aktywnych stowarzyszeń bibliotek kościelnych i można uznać je za reprezentatywne w omawianej kwestii. Statuty w sensie właściwym oznaczają zarządzenia wydawane zgodnie z prawem w zespołach osób lub rzeczy, określając ich cel, konstytucję, zarząd i sposoby działania $^{2}$, w związku z czym powstaje pytanie, jak w aspekcie prawnym, w świetle swoich statutów Stowarzyszenia Bibliotek Kościelnych w Polsce, Włoszech i Hiszpanii regulują cel, konstytucję, zarząd i sposoby swojego działania. Niniejszy artykuł może stać się przyczynkiem i punktem wyjścia do modelowego przedstawienia statutu stowarzyszenia bibliotekarzy kościelnych, który byłby pewną pomocą do wypracowywania jak najlepszych przepisów wewnętrznych wspomnianych stowarzyszeń. Jest to jednak problem wymagający osobnego opracowania.

\section{Natura, cele i sposoby dzialania Stowarzyszeń Bibliotek Kościelnych w Polsce, Wloszech i Hiszpanii}

Według Statutu Federacji Bibliotek Kościelnych „Fides” federacja jest publicznym stowarzyszeniem wiernych erygowanym na czas nieokreślony przez Konferencję Episkopatu Polski w dniu 18 marca 1995 r. zgodnie z kan. $312 \S 1$ nr 2 Kodeksu Prawa Kanonicznego i nabywa osobowość prawną kanoniczną zgodnie z kan. 313 KPK oraz osobowość cywilnoprawną w oparciu o art. $10 \mathrm{i}$ art. 341 pkt i ust. 3 ustawy z dnia 17 maja 1989 r. o stosunku Państwa do Kościoła katolickiego w Rzeczypospolitej (Dz.U. z 2013 r., poz. 1169 z późn. zm.) ${ }^{3}$. Z kolei zgodnie ze Estatutos de la Asociación de Bibliotecarios de la Iglesia en España Stowarzyszenie Bibliotekarzy Kościelnych w Hiszpanii jest kanonicznym stowarzyszeniem publicznym o zasięgu krajowym, niedochodowym (organizacja non-profit), erygowanym przez Hiszpańską Konferencję Biskupią na prośbę i po porozumieniu bibliotekarzy ${ }^{4}$. Natomiast Stowarzyszenie Bibliotekarzy Kościelnych Włoch jest niedochodowym (organizacja non-profit) stowarzyszeniem

${ }^{2}$ Codex Iuris Canonici. Auctoritate Ioannis Pauli PP. II promulgatus. Kodeks Prawa Kanonicznego, przekład polski zatwierdzony przez Konferencję Episkopatu, Poznań 1984, (dalej: KPK), kan. $94 \S 1$; por. kan. $304 \S 1$.

${ }^{3}$ Statut Federacji Bibliotek Kościelnych „Fides” (13 października 2017), http://www.fides. org.pl/pdf/Statut_nowy.pdf, (dalej: Statut „Fides”). Jest to trzeci i aktualny statut Federacji „Fides”.

${ }^{4}$ Por. Estatutos de la Asociación de Bibliotecarios de la Iglesia en España para la Defensa, conservación y difusión de su Patrimonio Bibliográfico (22 noviembre 2007), art. 1, el „Patrimonio cultural Documentación, estudios, información”, 46 (2007) s. 107-114, (dalej: Estatutos de la Asociación). 
ukonstytuowanym zgodnie z normami prawa kościelnego (kan. 321-326), własnym statutem i prawomocnym włoskim ustawodawstwem cywilnym ${ }^{5}$.

Co się tyczy celów ${ }^{6}$, to statut „Fides” zawiera następującą dyspozycję: celem Federacji jest działanie na rzecz ewangelizacyjnej misji Kościoła poprzez dbałość o rozwój polskich bibliotek kościelnych i usprawnienie informacji o ich zasobach, a w szczególności: włączenie bibliotek kościelnych w bieżące przemiany cywilizacyjne zwłaszcza w obszarze nowych technologii informacyjno-komunikacyjnych, zachowanie i promocja dziedzictwa kulturowego zgromadzonego w bibliotekach kościelnych, dokumentowanie działalności i popularyzowanie wiedzy o bibliotekach kościelnych, integrowanie środowiska bibliotekarzy kościelnych i przygotowanie ich do nowych wyzwań poprzez odpowiednie formy doskonalenia zawodowego ${ }^{7}$.

Natomiast statut Stowarzyszenia Bibliotekarzy Kościelnych w Hiszpanii następująco formułuje cele Stowarzyszenia: promowanie ochrony, konserwacji i rozpowszechniania nauki i katolickiej kultury religijnej oraz działalności duszpasterskiej Kościoła katolickiego przez posługę bibliotek kościelnych, przyczyniając się w ten sposób do realizacji misji edukacyjnej Kościoła; współpraca z katolicką hierarchią kościelną w celu właściwego wykorzystania w służbie społeczeństwa swojego dziedzictwa bibliograficznego, zgodnie z obowiązującymi umowami zawartymi w tej sprawie ${ }^{8}$. W związku z wymienionymi celami przywołany statut stwierdza, że dla ich lepszego osiągnięcia, Stowarzyszenie stawia sobie następujące zadania: wspierać w aspekcie historycznym, bibliograficznym oraz dokumentacyjnym różne katolickie instytucje kościelne zajmujące się formacją religijną i moralną wiernych, przyczyniać się w miarę swoich możliwości do właściwej konserwacji, organizacji i katalogowania bibliotek kościelnych Hiszpanii pod kierunkiem kompetentnych władz kościelnych i utrzymywać, w określonych ramach, kontakty z organami administracji cywilnej właściwymi dla bibliotek, popierać inwentaryzację i katalogowanie kościelnego dziedzictwa bibliograficznego Hiszpanii, jak również jego publikację, wspomagać formację swoich członków na temat bibliotek, popierać współpracę wśród członków Stowarzyszenia, by ułatwiać ich pracę i lepiej rozwiązywać wspólne problemy, promować odbywanie spotkań narodowych w celu studium i rozwoju działalności bibliotekarskiej oraz sprzyjać uczestnictwu swoich członków w spotkaniach narodowych czy międzynarodowych związanych z problematyką bibliotek, realizować wszelkie działania, które w sposób jasny prowadzą do zdobycia obszerniejszej wiedzy o miejscu bibliotek kościelnych w hiszpańskim systemie bibliotecznym i sprzyjać inicjatywom promującym biblioteki i bibliotekarzy kościelnych na bibliotekarskiej arenie narodowej i międzynarodowej ${ }^{9}$.

${ }^{5}$ Por. Statuto dell'Associazione dei Bibliotecari Ecclesiastici Italiani (2 aprile 2003), art. 1, 3, „Bollettino di informazione”, 23 (2003) fasc.1, s. 4-8, (odtąd: Statuto dell'Associazione).

${ }^{6}$ Kan. $304 \S 1$. „Wszystkie stowarzyszenia wiernych, zarówno publiczne, jak i prywatne, niezależnie od tego, jaki noszą tytuł lub nazwę, powinny mieć własne statuty, które określają cel stowarzyszenia, czyli przedmiot społeczny (...)”.

${ }^{7}$ Statut „Fides”, art. 8.

${ }^{8}$ Por. Estatutos de la Asociación, art. $4 \S 1$.

${ }^{9}$ Por. Estatutos de la Asociación, art. $4 \S 2$. 
Statuto dell'Associazione dei Bibliotecari Ecclesiastici Italiani stawia Stowarzyszeniu następujące cele: przyczyniać się, inspirując się dyspozycjami kanonicznymi i prawomocnym włoskim ustawodawstwem świeckim, do odpowiedniego utrzymania księgozbiorów kościelnych i do wzrostu bibliograficznego i funkcjonalnego, rekomendując je jako narzędzie ożywienia kulturalnego wspólnot chrześcijańskich i społeczeństwa; promować każdą inicjatywę służącą korzystniejszej działalności technicznej i naukowej członków Stowarzyszenia. Ważnym elementem w działalności Stowarzyszenia jest podtrzymywać obecność i reprezentację Stowarzyszenia w szerokim kontekście włoskiego i międzynarodowego systemu bibliotecznego, sprzyjając relacjom i konstruktywnemu dialogowi zarówno z państwowymi, jak i z lokalnymi organami ochrony i promocji oraz z instytucjami religijnymi i kulturalnymi ${ }^{10}$.

\section{Konstytucja Stowarzyszeń Bibliotek Kościelnych Polsce, Wloszech i Hiszpanii}

W kan. $94 \S 1$ ustawodawca kodeksowy stanowi, iż statuty w sensie właściwym winny w zespołach osób lub rzeczy określać oprócz celu także ich konstytucję, czyli wewnętrzną organizację. Przede wszystkim w obrębie przepisów o organizacji statuty Stowarzyszenia Bibliotek Kościelnych powinno mieć swoją nazwę ${ }^{11}$. W Kościele w Polsce nazwa ta brzmi: Federacja Bibliotek Kościelnych „Fides" ${ }^{2}$. Prawodawca podkreśla, że nazwa Federacji jest zastrzeżona i podlega ochronie prawnej ${ }^{13}$. Kościół w Hiszpanii posiada stowarzyszenie o nazwie: Asociación de Bibliotecarios de la Iglesia en España para la Defensa, conservación y difusión de su Patrimonio Bibliográfico ${ }^{14}$, a Kościół we Włoszech: Associazione dei Bibliotecari Ecclesiastici Italiani ${ }^{15}$.

Następnie Stowarzyszenie Bibliotek Kościelnych winno mieć swoją siedzibę $^{16}$. Siedzibą federacji „Fides” jest miasto stołeczne Warszawa ${ }^{17}$, Associazione dei Bibliotecari Ecclesiastici Italiani mieści się w Rzymie przy placu S. Maria Maggiore $n r 5^{18}$, a Asociación de Bibliotecarios de la Iglesia en España swoją centralę posiada w miejscu zamieszkania jego przewodniczącego. Jej miejsce może

\footnotetext{
${ }^{10}$ Por. Statuto dell'Associazione, art. 3.

${ }^{11}$ Kan. $304 \S 2$. Wszystkie stowarzyszenia wiernych, zarówno publiczne, jak i prywatne, ,powinny (...) obrać sobie tytuł, czyli nazwę, dostosowaną do zwyczajów czasu i miejsca, a szczególnie związaną z celem, do którego zmierzają".

${ }^{12}$ Statut „Fides”, art. 1.

${ }^{13}$ Tamże, art. 7, $\mathrm{nr} 2$.

${ }^{14}$ Estatutos de la Asociación, art. 1.

${ }^{15}$ Statuto dell' Associazione, art. 1.

${ }^{16}$ Kan. $304 \S 1$. Wszystkie stowarzyszenia wiernych, zarówno publiczne, jak i prywatne, niezależnie od tego, jaki noszą tytuł lub nazwę, powinny mieć własne statuty, które określają (...) siedzibę (...)".

${ }^{17}$ Statut „Fides”, art. 2, nr 1.

${ }^{18}$ Statuto dell'Associazione, art. 2.
} 
zostać zmienione na mocy decyzji Zarządu, który powiadamia o dokonanej zmianie Konferencję Episkopatu ${ }^{19}$.

Statut Federacji Bibliotek Kościelnych „Fides” stwierdza ponadto, że federacja używa własnego znaku graficznego (logo) i własnej pieczęci. Nazwa federacji i jej znaki graficzne podlegają ochronie zgodnie z przepisami prawa oraz, że patronem federacji jest św. Maksymilian Maria Kolbe ${ }^{20}$.

Stowarzyszenie Bibliotekarzy Kościelnych winno posiadać określoną strukturę. Federacja Bibliotek Kościelnych „Fides” ma następująca strukturę: walne zgromadzenie jako najwyższa władza federacji, zarząd i komisja rewizyjna ${ }^{21}$. Stowarzyszenie Bibliotekarzy Kościelnych Włoch posiada: zarząd ${ }^{22}$, przewodniczacego i wiceprzewodniczącego ${ }^{23}$, sekretariat ${ }^{24}$, skarbnika ${ }^{25}$ i komisję rewizyjną ${ }^{26}$. Wreszcie Asociación de Bibliotecarios de la Iglesia en España składa się z: walnego zgromadzenia członków i zarządu ${ }^{27}$, który stanowią: przewodniczący, wiceprzewodniczący, sekretarz, skarbnik i trzech członków ${ }^{28}$.

Stowarzyszenie Bibliotekarzy Kościelnych jest stowarzyszeniem publicznym, tzn. erygowanym przez kompetentną władzę kościelną (Konferencję Episkopatu $)^{29}$, zrzeszającym osoby fizyczne należące do Kościoła katolickiego, reprezentujące biblioteki kościelne ${ }^{30}$. Zgodnie z kan. $316 \S 1$ nie może być członkiem stowarzyszenia publicznego, a więc i bibliotekarzy kościelnych ten, kto publicznie odstąpił od wiary katolickiej albo zerwał wspólnotę kościelną, albo podlega ekskomunice nałożonej wyrokiem lub zdeklarowanej. Trzeba dodać, że członek Stowarzyszenia Bibliotekarzy Kościelnych może się zapisać do kilku innych stowarzyszeń $^{31}$.

Statuty poszczególnych stowarzyszeń przewidują różne kategorie członków. W Federacji Bibliotek Kościelnych „Fides” członkostwo może przybierać formy: zwyczajnego, wspierającego i honorowego ${ }^{32}$.

Członkiem zwyczajnym federacji może być osoba fizyczna należąca do Kościoła katolickiego, reprezentująca bibliotekę kościelną w Polsce posiadającą osobowość prawną (bibliotekę reprezentuje w Federacji osoba kierująca biblioteką lub inna wskazana przez właściwą władzę; każda biblioteka może być reprezen-

${ }^{19}$ Estatutos de la Asociación, art. 3.

${ }^{20}$ Statut ,Fides”, art. 6-7.

${ }^{21}$ Tamże, art. 21.

${ }^{22}$ Statuto dell'Associazione, art. 13.

${ }^{23}$ Tamże, art. 17-18.

${ }^{24}$ Tamże, art. 17.

${ }^{25}$ Tamże, art. 21.

${ }^{26}$ Tamże, art. 23.

${ }^{27}$ Estatutos de la Asociación, art. 15.

${ }^{28}$ Tamże, art. 20.

${ }^{29}$ Por. kan. $301 \S 3,312 \S 2$; Statut „Fides”, art. 1; zob. Statuto dell'Associazione, art. 17; Estatutos de la Asociación, art. 1.

${ }^{30}$ Por. kan. 215. Statut Federacji Bibliotek Kościelnych „Fides” postanawia: „federacja zrzesza osoby fizyczne i osoby prawne. Osoba prawna może być jedynie członkiem wspierającym”. Art. 10.

${ }^{31} \mathrm{Kan} .307 \S 2$.

${ }^{32}$ Statut ,Fides”, art. 11. 
towana tylko przez jednego członka zwyczajnego) lub bibliotekę na terenie Polski należącą do kościelnej osoby prawnej, a także bibliotekę uczelni, wydziału lub innej instytucji pozostającej w całości lub w części pod nadzorem władz Kościoła katolickiego ${ }^{33}$. Członkami wspierającymi mogą być osoby fizyczne i osoby prawne deklarujące pomoc materialną, rzeczową lub merytoryczną dla realizacji celów statutowych Federacji ${ }^{34}$. Członkami honorowymi mogą być osoby fizyczne, które wniosły wybitny wkład w działalność i rozwój Federacji35.

Statut Stowarzyszenia Bibliotekarzy Kościelnych Włoch przewiduje następujące rodzaje członków: członkowie zwyczajni, wspierający (sympatycy) oraz honorowi. Członkowie zwyczajni to ci, który pracują albo pracowali w bibliotekach podległych władzy kościelnej lub mają szczególne zasługi dla kościelnego życia kulturalnego, jak również znawcy dyscyplin bibliotekarskich. Członkowie wspierający (sympatycy) to osoby, które zamierzają finansowo przyczyniać się do funkcjonowania Stowarzyszenia i których prośba o przystąpienie do Stowarzyszenia została pozytywnie przyjęta przez Zarząd. Wreszcie członkowie honorowi są powoływani do udziału w życiu Stowarzyszenia ze względu na wybitne zasługi dla bibliotek kościelnych lub są zasłużone wobec Stowarzyszenia ${ }^{36}$.

Estatutos de la Asociación de Bibliotecarios de la Iglesia en España ustanawia dwie kategorie członków Stowarzyszenia: członkowie zwyczajni i honorowi ${ }^{37}$. Członkami zwyczajnymi Stowarzyszenia mogą być ci wszyscy, którzy dowiodą, iż pełnią na stałe stanowisko bibliotekarza lub asystenta bibliotekarza w bibliotekach kapitulnych, diecezjalnych, seminaryjnych, monastycznych, klasztornych, uniwersyteckich, w fakultetach i centrach studiów katolickich lub w bibliotekach powiązanych z innymi instytucjami kościelnymi. Osoby te stają się członkami z pełnią praw i obowiązków od chwili przejęcia ich prośby o członkostwo przez Zarząd Stowarzyszenia. Koniecznym warunkiem bycia członkiem zwyczajnym jest wykonywanie urzędu kościelnego lub innej funkcji, jak również płaceniem na bieżąco składek ${ }^{38}$. Członkiem honorowym mogą być osoby fizyczne albo prawne, które mają lub miały wybitne zasługi na rzecz bibliotek kościelnych lub wspierają Stowarzyszenie swoją skuteczną pomocą moralną czy ekonomiczną. Bibliotekarze kościelni, którzy w swoich własnych bibliotekach otrzymali status ,emerytów" albo faktyczni emeryci, także będą mogli być uhonorowani wyróżnieniem jako członkowie honorowi ${ }^{39}$.

Kan. 307 § 1 KPK stanowi, że przyjmowanie członków winno się dokonywać zgodnie z przepisami prawa i statutami każdego stowarzyszenia. Statut „Fides” zawiera w tej kwestii następujące dyspozycje: członków zwyczajnych przyjmuje

${ }^{33}$ Tamże, art. 12.

${ }^{34}$ Por. Statut ,Fides”, art. 16, nr 1.

${ }^{35}$ Tamże, art. 17, nr 1.

${ }^{36}$ Statuto dell'Associazione, art. 7.

${ }^{37}$ Estatutos de la Asociación, art. 5.

${ }^{38}$ Tamże, art. 6.

${ }^{39}$ Estatutos de la Asociación, art. $7 \S 1$. Trzeba dodać, że członkowie honorowi, którzy mają status osób prawnych, wykonają swoje prawa i obowiązki za pośrednictwem swoich prawnych przedstawicieli odpowiednio potwierdzonych przez Zarząd. Tamże, art. 7 § 2 . 
Zarząd w trybie uchwały na podstawie pisemnego wniosku o przyjęcie do Federacji zawierającego: oświadczenie właściwej władzy, której biblioteka podlega, wskazujące osobę reprezentującą bibliotekę w Federacji, oświadczenie reprezentanta o przyjęciu Statutu, zwięzłą charakterystykę biblioteki ${ }^{40}$. Członkostwo wspierające (osoba fizyczna lub prawna) nabywa się na podstawie deklaracji pomocy finansowej, rzeczowej lub merytorycznej w celu realizacji celów Federacji. Członkiem wspierającym staje się po złożeniu pisemnej deklaracji na podstawie uchwały Zarządu. Członek wspierający ma obowiązek wywiązywania się z zadeklarowanych świadczeń, przestrzegania Statutu oraz uchwał władz Federacji ${ }^{41}$. Członkiem honorowym Federacji może być osoba fizyczna, która wniosła wybitny wkład w działalność i rozwój Federacji. Członkostwo honorowe nadaje Walne Zgromadzenie na wniosek Zarządu lub przynajmniej dziesięciu członków zwyczajnych Federacji ${ }^{42}$. Członkowie wspierający i honorowi nie posiadają biernego ani czynnego prawa wyborczego oraz nie mają obowiązku płacenia składek członkowskich ${ }^{43}$.

Według Statuto dell'Associazione dei Bibliotecari Ecclesiastici Italiani członkami zwyczajnymi Stowarzyszenia są osoby, których prośba o przyjęcie została przyjęta przez Zarząd i które wpłaciły przy przyjęciu składki na Stowarzyszenie uzgadniane corocznie przez Zarząd. Członkowie, którzy nie przedstawią na piśmie swojej rezygnacji do dnia 30 października każdego roku, będą uwzględniani jako członkowie także w następnym roku i zobowiązani do wpłacania składki rocznej na Stowarzyszenie ${ }^{44}$. Członkowie wspierający, zobowiązujący się do niesienia pomocy finansowej Stowarzyszeniu, przystępują do Stowarzyszenia po pozytywnym przyjęciu ich prośby przez Radę Zarządzającą ${ }^{45}$. Natomiast członkowie honorowi są mianowani dożywotnio przez Walne Zgromadzenie ${ }^{46}$.

W przypadku Stowarzyszenia Bibliotekarzy Kościelnych Hiszpanii członkami zwyczajnymi z pełnią praw i obowiązków stają się osoby od chwili przyjęcia ich prośby o członkostwo przez Zarząd Stowarzyszenia ${ }^{47}$. Natomiast członkowie honorowi zostają powołani przez Walne Zgromadzenie na uprzedni wniosek Zarządu lub któregoś z członków ${ }^{48}$. Trzeba dodać, że omawiane Stowarzyszenie winno prowadzić rejestr swoich członków, w których figurują przynajmniej następujące dane: imię i nazwisko lub, tam gdzie stosowne, nazwa instytucji, pełniona funkcja (w przypadku osoby fizycznej), adres i miejsce zamieszkania, numer identyfikacji podatkowej (D.N.I.), ewentualnie C.I.F (numer systemu identyfikacji podatkowej

\footnotetext{
${ }^{40}$ Statut ,Fides”, art. 13.

${ }^{41}$ Tamże, art. 16.

${ }^{42}$ Statut ,Fides”, art. 17.

${ }^{43}$ Tamże, art. 18.

${ }^{44}$ Statuto dell'Associazione, art. 6.

${ }^{45}$ Tamże, art. 7.

${ }^{46}$ Statuto dell'Associazione, art. 7.

${ }^{47}$ Estatutos de la Asociación, art. $6 \S 2$.

${ }^{48}$ Tamże, art. $7 \S 1$.
} 
stosowanej w Hiszpanii w przypadku osób prawnych do 2008 r.), data wstąpienia do Stowarzyszenia ${ }^{49}$.

Statuty Stowarzyszenia Bibliotekarzy Kościelnych przewidują także utratę członkostwa, która może nastąpić zgodnie z przepisami prawa i statutów ${ }^{50}$. Na podstawie prawa kodeksowego, tak jak w każdym stowarzyszeniu kościelnym, tak w Stowarzyszeniu Bibliotekarzy Kościelnych ten, kto został prawnie przyjęty do Stowarzyszenia, nie może być z niego usunięty, chyba że na skutek słusznej przyczyny, zgodnie z przepisami prawa i statutów ${ }^{51}$. Natomiast ci, którzy zgodnie z przepisami prawa zostali przyjęci do stowarzyszenia publicznego, a takim jest omawiane w artykule Stowarzyszenie Bibliotekarzy Kościelnych, gdyby odstąpili od wiary katolickiej albo zerwali wspólnotę kościelną, albo podlegali ekskomunice nałożonej wyrokiem lub zdeklarowanej, po uprzednim upomnieniu powinni być wydaleni ze stowarzyszenia, z zachowaniem postanowień jego statutów i zachowaniem prawa rekursu do władzy kościelnej, w tym wypadku do Konferencji Episkopatu i organów stowarzyszenia zgodnie ze statutem ${ }^{52}$. Wierny wykluczony ze stowarzyszenia publicznego (tutaj Stowarzyszenia Bibliotekarzy Kościelnych) ma prawo wnieść rekurs do drugiej sekcji Sygnatury Apostolskiej z zachowaniem procedury administracyjnej ${ }^{53}$.

Według Statutu Federacji Bibliotek Kościelnych „,Fides” utrata członkostwa w Stowarzyszeniu następuje na skutek: utraty reprezentacji biblioteki, pisemnej rezygnacji złożonej do Zarządu Federacji, likwidacji reprezentowanej biblioteki, wydalenia przez Zarząd w trybie uchwały: $\mathrm{z}$ powodu nieprzestrzegania statutu lub uchwał władz Federacji, z powodu notorycznego niebrania udziału w pracach Federacji, z powodu niepłacenia składek przez dwa lata, z powodu utraty przynależności do Kościoła katolickiego zgodnie z kan. 316 KPK, utraty praw obywatelskich na mocy prawomocnego wyroku sądu, utratę osobowości prawnej przez osoby prawne, śmierci członka ${ }^{54}$. Od uchwały Zarządu w sprawie przyjęcia w poczet członków Federacji lub pozbawienia członkostwa przysługuje zainteresowanemu odwołanie do Walnego Zgromadzenia, a następnie do nadrzędnej władzy kościelnej ${ }^{55}$.

Według Statuto dell'Associazione dei Bibliotecari Ecclesiastici Italiani członkostwo traci się poprzez śmierć, rezygnację i wydalenie. Wydalenie jest deklarowane przez Zarząd za niepłacenie składek lub wskutek rażącego naruszenia zasad statutowych ${ }^{56}$. Natomiast utrata stanu członka zwyczajnego w Stowarzyszeniu Bibliotekarzy Kościelnych Hiszpanii następuje poprzez zrzeczenie zakomunikowane Zarządowi, przez zrzeczenie milczące - kiedy stowarzyszony zaprzestaje

\footnotetext{
49 Tamże, art. 14.

${ }^{50}$ Zob. kan. 306.

${ }^{51}$ Kan. 308.

${ }^{52}$ Kan. 316; por. kan. $312 \S 1$, nr 2.

${ }^{53}$ J. Krukowski, Komentarz do kan. 316, w: Komentarz do Kodeksu Prawa Kanonicznego. T. 2. Ks. II (1). Lud Boży, red. J. Krukowski, Poznań 2005, s. 142.

${ }^{54}$ Statut ,Fides”, art. 19, nr 1.

${ }^{55}$ Tamże, art. 20.

${ }^{56}$ Statuto dell'Associazione, art. 8.
} 
opłacać składkę roczną przez trzy kolejne lata po uprzednim pisemnym zakomunikowaniu, aby uregulował swoją sytuację w terminie sześciu miesięcy, a mimo tego nadal nic nie czyni w tej sprawie, po opuszczeniu stanowiska bibliotekarza, na mocy uchwały Zarządu zatwierdzonej przez Walne Zgromadzenie w przypadkach przewidzianych w kan. 316, jak również w wypadku poważnego niezastosowania się do statutów albo działania szkodliwego dla dobra Stowarzyszenia, jeśli po jednorazowym upomnieniu nadal trwa $\mathrm{w}$ takim postępowaniu ${ }^{57}$. Utrata członkostwa honorowego następuje przez osobistą decyzję zainteresowanego zakomunikowaną Zarządowi oraz w przypadku, gdy wobec niego weryfikują się postanowienia art. $8 \mathrm{~d}$ statutu $^{58} \mathrm{w}$ tym, co może mieć zastosowanie do niego, w zależności od tego, czy mówi się o osobach fizycznych lub instytucjach i osobach prawnych ${ }^{59}$.

Z członkostwem w Stowarzyszeniu łączą się w sposób ścisły prawa i obowiązki. Statut Federacji Bibliotek Kościelnych „Fides” ukazuje następujące prawa członków zwyczajnych Stowarzyszenia: uczestniczenie w działalności Federacji i realizacji jej celów, przestrzeganie Statutu i uchwał władz Federacji, regularne opłacanie składek, przestrzeganie norm i zasad etycznych ${ }^{60}$.

Stowarzyszenie Bibliotekarzy Kościelnych Włoch nie podaje expressis verbis praw i obowiązków członków Stowarzyszenia. Jednak z lektury statutu można stwierdzić, że członkowie honorowi, jak również zwyczajni i sympatycy opłacający składki roczne Stowarzyszenia z zasady mają prawo brać udział w zebraniach Stowarzyszenia ${ }^{61}$. Suponuje to, że członkowie zwyczajni mogą korzystać z czynnego i biernego prawa wyborczego. W przypadku sporów między członkami oraz między członkami a Stowarzyszeniem lub jego organami, wchodzący w spór członkowie maja prawo odwołać się do sądu polubownego złożonego z trzech arbitrów powołanych przez Walne Zgromadzenie, którzy będą oceniać na zasadzie słuszności bez formalnej procedury powstały spór. Wyrok sądu polubownego jest bezapelacyjny ${ }^{62}$.

Asociación de Bibliotecarios de la Iglesia en España zapewnia swoim członkom zwyczajnym następujące prawa: uczestniczenie z prawem zabrania głosu i głosowanie w obradach i decyzjach zgromadzenia ogólnego, wybieranie i bycie wybieranym do Zarządu, proponowanie Zarządowi zagadnienia i inicjatywy pożytecznej dla realizacji celów Stowarzyszenia, reprezentowanie Stowarzyszenie jako delegat zgromadzenia ogólnego albo Zarządu w wydarzeniach narodowych

${ }^{57}$ Estatutos de la Asociación, art. 8.

${ }^{58}$ Art. 8 d statutu: ,,członek Stowarzyszenia Bibliotekarzy Kościelnych w Hiszpanii zostaje usunięty na mocy uchwały zarządu zatwierdzonej przez walne zgromadzenie w przypadkach przewidzianych w kan. 316 [«kto publicznie odstąpił od wiary katolickiej albo zerwał wspólnotę kościelną, albo podlega ekskomunice nałożonej wyrokiem lub zdeklarowanej» kan. $316 \S 1$ ], jak również w wypadku poważnego niezastosowania się do Statutów albo działania szkodliwego dla dobra Stowarzyszenia jeśli, po jednorazowym upomnieniu, nadal trwa w takim postępowaniu".

${ }^{59}$ Estatutos de la Asociación, art. 9.

${ }^{60}$ Statut ,Fides”, art. 15.

${ }^{61}$ Statuto dell'Associazione, art. 11.

${ }^{62}$ Tamże, art. 26. 
albo międzynarodowych; bycie członkiem komisji, grupy roboczej, sekcji itd., otrzymywanie informacji i publikacji dotyczących działania Stowarzyszenia ${ }^{63}$. Obowiązki członków zwyczajnych omawianego Stowarzyszenia są następujące: respektować i przestrzegać aktualnego statutu, uchwał zgromadzenia ogólnego i dyspozycji Zarządu, na bieżąco wpłacać składkę roczną, przyjętą przez zgromadzenie ogólne, co stanowi warunek korzystania z praw statutowych, wykonywać zadania i obowiązki z polecenia Zarządu ${ }^{64}$. Natomiast prawa członków honorowych są następujące: brać udział w obradach zebrania z prawem zabrania głosu, lecz bez głosowania, otrzymywać informacje i publikacje dotyczące funkcjonowania Stowarzyszenia, korzystać z bonifikaty składek rocznych ustalonych przez zgromadzenie ogólne, proponować Zarządowi i Zgromadzeniu Walnemu zagadnienia i inicjatywy pożyteczne dla realizacji celów Stowarzyszenia ${ }^{65}$. Wreszcie obowiązki członków honorowych są takie: respektować i przestrzegać aktualnych statutów w tym wszystkim, co odnosi się do nich, respektować i przestrzegać uchwał zgromadzenia ogólnego i dyspozycji Zarządu, uczestniczyć w utrzymywaniu Stowarzyszenia, wpłacając składkę roczną ustaloną przez Walne Zgromadzenie, jako warunek korzystania przyznanych im praw statutowych, wykonywać zadania albo funkcje przyjęte na zlecenie Zarządu ${ }^{66}$.

\section{Władze Stowarzyszeń Bibliotek Kościelnych Polsce, Wloszech i Hiszpanii}

Zgodnie z kan. $304 \S 1$ wszystkie stowarzyszenia wiernych, zarówno publiczne, jak i prywatne, niezależnie od tego, jaki noszą tytuł lub nazwę, powinny mieć własne statuty, które określają m.in. zarząd stowarzyszenia ${ }^{67}$. Do statutu stowarzyszenia powinny być wpisane elementy indywidualne i istotne dla każdego stowarzyszenia, określające m.in. Zarząd, tzn. winny być wskazane organy stowarzyszenia, ich skład i zadania, sposoby nominacji członków zarządu, informacje co do tego, kto reprezentuje legalnie Stowarzyszenie ${ }^{68}$. Statut Federacji Bibliotek Kościelnych „Fides” podaje, że władzami federacji są: Walne Zgromadzenie jako najwyższa władza Federacji, Zarząd i Komisja Rewizyjna. Kadencja wybieralnych władz trwa trzy lata, a ich wybór odbywa się w głosowaniu tajnym bezwzględną większością głosów. Członkowie wybrani do władz Federacji mogą pełnić swoją funkcję w tym samym organie nie dłużej niż przez dwie kadencje, chyba że w wyborach na kolejne kadencje otrzymają co najmniej 2/3 głosów ${ }^{69}$. Uchwały wszystkich władz Federacji zapadają zwykłą większością głosów przy obecności co najmniej połowy członków uprawnionych do głosowania, chyba że dalsze postanowienia Statutu stanowią inaczej ${ }^{70}$.

\footnotetext{
${ }^{63}$ Estatutos de la Asociación, art. 10.

${ }^{64}$ Tamże, art. 11.

${ }^{65}$ Tamże, art. 12.

${ }^{66}$ Tamże, art. 13.

${ }^{67}$ Zob. kan. $94 \S 1$.

${ }^{68}$ Por. J. Krukowski, Komentarz do kan. 304, w: Komentarz do Kodeksu Prawa Kanonicznego.

T. 2. Ks. II (1). Lud Boży, s. 130.

${ }^{69}$ Statut ,Fides”, art. 21-22.

${ }^{70}$ Tamże, art. 23.
} 
Walne Zgromadzenie jest najwyższą władzą Federacji. W Walnym Zgromadzeniu biorą udział: 1) z głosem stanowiącym - członkowie zwyczajni lub ich pełnomocnicy; 2) z głosem doradczym - członkowie wspierający, honorowi oraz zaproszeni goście. Są dwa rodzaje Walnego Zgromadzenia: zwyczajne i nadzwyczajne. Walne Zgromadzenie zwyczajne jest zwoływane raz w roku przez Zarząd. Czas i miejsce obrad Zarząd podaje do wiadomości wszystkich członków co najmniej na 30 dni przed terminem zebrania, natomiast Walne Zgromadzenie nadzwyczajne jest zwoływane przez Zarząd z jego inicjatywy, na wniosek Komisji Rewizyjnej lub pisemny wniosek co najmniej 1/3 ogólnej liczby członków zwyczajnych Federacji. Uchwały Walnego Zgromadzenia zapadają bezwzględną większością głosów w głosowaniu jawnym, w obecności przynajmniej połowy ogólnej liczby członków zwyczajnych Federacji lub ich pełnomocników w pierwszym terminie, a bez względu na liczbę członków w drugim terminie. Głosowanie tajne wymaga wniosku co najmniej jednego uczestnika głosowania. Sposób przeprowadzania i przebieg Walnego Zgromadzenia określa Regulamin Walnego Zgromadzenia zatwierdzony przez to Zgromadzenie ${ }^{71}$. Statut „Fides” określa następujące uprawnienia Walnego Zgromadzenia, jako najwyższej władzy Federacji: 1) określenie głównych kierunków działania i rozwoju Federacji; 2) uchwalanie zmian Statutu Federacji; 3) wybór i odwoływanie władz Federacji; 4) udzielanie Zarządowi absolutorium na wniosek Komisji Rewizyjnej; 5) rozpatrywanie i zatwierdzanie sprawozdań Zarządu i Komisji Rewizyjnej; 6) zatwierdzanie rozliczeń finansowych w postaci bilansów rocznych; 7) uchwalanie wysokości składek członkowskich oraz wszystkich innych świadczeń na rzecz Federacji; 8) podejmowanie decyzji o prowadzeniu przez Federację działalności gospodarczej oraz uchwalenie jej regulaminu; 9) podejmowanie uchwał w sprawie nadania członkostwa honorowego; 10) rozpatrywanie wniosków i postulatów zgłoszonych przez członków Federacji lub jej władze; 11) rozpatrywanie odwołań od uchwał Zarządu; 12) podejmowanie uchwał o członkostwie Federacji w innych organizacjach; 13) podejmowanie uchwał w każdej innej sprawie wniesionej pod obrady i nie zastrzeżonej innym organom władz Federacji; 14) podjęcie uchwały o woli rozwiązania Federacji ${ }^{72}$.

Organem wykonawczym Federacji jest Zarząd. W jego skład Zarządu wchodzi pięciu członków: 1) Przewodniczący Zarządu; 2) Zastępca Przewodniczącego Zarządu; 3) Sekretarz Zarządu; 4) Skarbnik; 5) Członek Zarządu³.

Zarząd wybierany jest przez Walne Zgromadzenie według zatwierdzonego regulaminu wyborów. W głosowaniu bezpośrednim Walne Zgromadzenie wybiera Przewodniczącego Zarządu, a pozostałych jako członków Zarządu. Zastępcę Przewodniczącego Zarządu, Sekretarza Zarządu i Skarbnika, Zarząd wybiera spośród swoich członków na pierwszym posiedzeniu jeszcze podczas trwającego Walnego Zgromadzenia. Wybór Zarządu wymaga zgłoszenia i zatwierdzenia przez Konferencję Episkopatu Polski. Kadencja Zarządu rozpoczyna się z dniem zatwierdzenia przez Konferencję Episkopatu Polski. Osobą sprawującą funkcję

\footnotetext{
71 Tamże, art. 24-27.

72 Tamże, art. 28.

${ }^{73}$ Tamże, art. 29.
} 
organu Federacji, uprawnioną do jej reprezentowania, jest Przewodniczący Zarządu. W poszczególnych sprawach może on udzielić pełnomocnictwa innemu członkowi Zarządu. Każdy członek Zarządu może być odwołany w trakcie kadencji uchwałą Walnego Zgromadzenia podjętą większością co najmniej 2/3 głosów. W przypadku wakatu lub niemożności pełnienia funkcji Przewodniczącego Zarządu jego zadania i władzę przejmuje do najbliższego zwyczajnego Walnego Zgromadzenia Zastępca Przewodniczącego Zarządu. W szczególnych okolicznościach w miejsce Przewodniczącego Zarządu może zostać powołany pełnomocnik do przejściowego kierowania Zarządem zgodnie z kan. 318 § 1 KPK. Posiedzenia Zarządu odbywają się w miarę potrzeb, nie rzadziej jednak niż dwa razy w roku. Posiedzenia Zarządu zwołuje jego Przewodniczący. Nadzwyczajne posiedzenie Zarządu może być zwołane na wniosek Komisji Rewizyjnej zgodnie z art. 37 pkt 5 Statutu. Uchwały Zarządu zapadają zwykłą większością głosów. W przypadku równej liczby głosów decyduje głos Przewodniczącego Zarządu ${ }^{74}$.

Kompetencje Zarządu „Fides” przedstawiają się następująco: 1) realizacja celów Federacji; 2) kierowanie bieżącą działalnością Federacji; 3) wykonywanie uchwał Walnego Zgromadzenia; 4) przygotowywanie projektów uchwał przed Zwyczajnym Walnym Zgromadzeniem; 5) sporządzanie planów pracy; 6) sprawowanie zarządu nad majątkiem Federacji; 7) proponowanie wysokości składki członkowskiej oraz zasad jej płatności; 8) podejmowanie i kierowanie działalnością gospodarczą oraz tworzenie $\mathrm{w}$ tym celu odpowiednich jednostek organizacyjnych; 9) zwoływanie Walnego Zgromadzenia; 10) przyjmowanie i usuwanie członków zwyczajnych i wspierających; 11) powoływanie i odwoływanie komisji problemowych i innych organów pomocniczych oraz sporządzanie ich regulaminów; 12) składanie dorocznych sprawozdań, także finansowych; 13) rozwiązywanie innych spraw niezastrzeżonych statutowo innym organom ${ }^{75}$. Trzeba dodać, że Zarząd składa co roku do Sekretariatu Konferencji Episkopatu Polski sprawozdanie z działalności, także finansowej zgodnie z kan. $319 \mathrm{KPK}^{76}$.

Komisja Rewizyjna, jako jedna z władz Federacji, jest powoływana do sprawowania kontroli nad działalnością Federacji. W skład Komisji Rewizyjnej wchodzi trzech członków: 1) Przewodniczący Komisji; 2) Sekretarz Komisji; 3) Członek Komisji. 3. Członków Komisji Rewizyjnej wybiera Walne Zgromadzenie. Przewodniczącego Komisji i Sekretarza Komisji wybiera Komisja Rewizyjna spośród siebie na pierwszym posiedzeniu, które powinno odbyć się jeszcze podczas trwającego Walnego Zgromadzenia, zwykłą większością głosów, w obecności wszystkich członków Komisji Rewizyjnej. Do kompetencji Komisji Rewizyjnej należy: 1) kontrolowanie działalności Federacji i Zarządu, zwłaszcza spraw finansowych; 2) składanie Walnemu Zgromadzeniu wniosków z kontroli; 3) składanie Walnemu Zgromadzeniu sprawozdań ze swojej działalności; 4) składanie wniosków o absolutorium dla Zarządu; 5) prawo składania wniosku o zwołanie nadzwyczajnego Walnego Zgromadzenia oraz nadzwyczajnego zebrania Zarządu ${ }^{77}$.

\footnotetext{
74 Tamże, art. 30-33.

75 Tamże, art. 34.

76 Tamże, art. 35.

77 Tamże, art. 36-37.
} 
Należy wspomnieć, iż w przypadku gdy skład organów władz Federacji zmniejszy się w czasie trwania kadencji, uzupełnienie ich składu może nastąpić w drodze kooptacji, której dokonują pozostali członkowie organu, który uległ zmniejszeniu. W tym trybie można powołać nie więcej niż $1 / 3$ składu organu ${ }^{78}$. Statut również stanowi, że członkowie władz statutowych „Fides” nie otrzymują wynagrodzenia ${ }^{79}$.

W Statuto dell'Associazione dei Bibliotecari Ecclesiastici Italiani stwierdza się, że Stowarzyszenie jest kierowane przez Radę Zarządzającą złożoną z dziewięciu członków wybranych przez Walne Zebranie. Radni pełnią urząd przez pięć lat i nie dłużej niż dwie kolejne kadencje. W przypadku rezygnacji lub śmierci radnego zastępuje go pierwszy z niewybranych, który wykonuje swoją funkcję aż do ukończenia kadencji. Zastąpienie przewodniczącego jest zastrzeżone uchwale zebrania powszechnego. Na swoim pierwszym zebraniu Rada Zarządzająca wybiera spośród swoich członków wiceprzewodniczącego, skarbnika i sekretarza, który może być wybrany także z poza rady. Nikt z członków Rady Zarządzającej nie ma prawa do wynagrodzenia $\mathrm{z}$ wyjątkiem zwrotów wydatków poniesionych zgodnie z regulaminem. Rada Zarządzająca zbiera się przynajmniej dwa razy w roku na zaproszenie przewodniczącego lub na wniosek większości członków. Do ważności uchwał jest potrzebna faktyczna obecność większości członków rady i głosów przychylnych większości obecnych; w przypadku równej liczby głosów przeważa głos przewodniczącego rady. Rada Zarządzająca jest kierowana przez przewodniczącego; w wypadku jego nieobecności przez wiceprzewodniczącego; pod nieobecność obydwu, przez starszego radnego. Ze spotkań rady redagowany jest protokół, podpisywany przez przewodniczącego i sekretarza. Radzie Zarządzającej przysługują pełne uprawnienia dla zwyczajnego i nadzwyczajnego zarządzania Stowarzyszeniem ${ }^{80}$.

Przewodniczący Rady Zarządzającej jest wybierany przez zebranie i obejmuje swój urząd po potwierdzeniu ze strony Konferencję Biskupów Włoch. Sprawuje swój urząd pięć lat i nie może pełnić swojej funkcji dłużej niż przez dwie kolejne kadencje Zadaniem przewodniczącego jest reprezentowanie Stowarzyszenia, kierowanie działalnością Stowarzyszenia i gwarantowanie poszanowania procedur w jego działaniu, zwoływanie i przewodniczenie zebraniom Rady Zarządzającej i określanie ich porządku dziennego; zagwarantowanie wykonania uchwał Zarządu, zgodnie ze statutem i regulaminem, utrzymywanie kontaktu z Konferencją Biskupów Włoch, Ministerstwem Kultury i ogólnie dbanie o zewnętrzne relacje Stowarzyszenia. Przewodniczący jest wspomagany przez wiceprzewodniczącego ${ }^{81}$. Sekretarz stale monitoruje działalność Stowarzyszenia i troszczy się o kontakty między członkami Stowarzyszenia, dba o korespondencję, dokumentację, archiwum, zgodnie z uchwałami Rady Zarządzającej. W celu właściwego wykonania wspomnianych obowiązków może zaproponować Radzie Zarządzającej współpracę z osobami z poza Stowarzyszenia (za wynagrodzeniem). Przewodniczą-

\footnotetext{
${ }^{78}$ Tamże, art. 38.

${ }^{79}$ Tamże, art. 39.

${ }^{80}$ Statuto dell'Associazione, art. 13-16.

${ }^{81}$ Tamże, art. 17-18.
} 
cy, wiceprzewodniczący zastępca i sekretarz tworzą w radzie prezydium, mogą w pilnych przypadkach sprawować funkcje Rady Zarządzającej, lecz ich decyzje muszą być ratyfikowane na najbliższym Walnym zebraniu ${ }^{82}$. W skład Zarządu wchodzi także skarbnik, który troszczy się o administrację majątku, zajmuje się przechowaniem ksiąg rachunkowych i odpowiada za finanse. Do niego należy przygotowanie budżetu i bilansu. W bieżącej działalności administracyjnej przewodniczący, wiceprzewodniczący i skarbnik mogą pracować niezależnie, korzystając z zasobów finansowych Stowarzyszenia. W przypadku operacji, które wykraczają poza zwykłą administrację, wymaga się aprobaty rady zarządzającej ${ }^{83}$.

Statut przewiduje także Komisję Rewizyjną jako organ kontrolny. Kierowanie Stowarzyszeniem jest kontrolowane przez komisję rewizyjną (Collegio dei Revisori dei Conti), tworzoną przez trzech członków faktycznych i dwóch zastępców, wybieranych spośród członków przez Walne Zgromadzenie. Wykonują oni swój urząd przez pięć lat i nie mogą pełnić swojej funkcji dłużej niż przez dwie kolejne kadencje. Rewizorzy winni kontrolować prawidłowe prowadzenie księgowości oraz sporządzać corocznie sprawozdanie dla przedstawienia go Walnemu Zgromadzeniu. Mogą kontrolować finanse Stowarzyszenia oraz istnienie walorów (papierów wartościowych) i tytułów własności oraz mogą w dowolnym momencie, nawet indywidualnie, dokonywać aktów inspekcji i kontroli ${ }^{84}$.

Odnośnie do zebrań, to członkowie zwyczajni, sympatycy i honorowi są zwoływani przez przewodniczącego przynajmniej raz w roku do dnia 30 czerwca $\mathrm{w}$ drodze zawiadomienia opublikowanego w siedzibie Stowarzyszenia lub udostępnianego w inny sposób ustalony przez Radę Zarządzającą co najmniej piętnaście dni przed wyznaczonym terminem zgromadzenia. Zawiadomienie ma zawierać porządek dnia, miejsce, godzinę i datę spotkania. Każdy członek może być reprezentowany przez innego członka za pośrednictwem pisemnego upoważnienia. Nikt nie może reprezentować więcej niż dwóch członków. Spotkanie może być także zwołane poza siedzibą Stowarzyszenia ${ }^{85}$. Zebraniu przewodniczy przewodniczący Stowarzyszenia albo zastępczo wiceprzewodniczący. Pod nieobecność obu, przewodniczy starszy radny. Do przewodniczącego zebrania należy stwierdzić prawidłowość pełnomocnictw i ogólnie prawo zabierania głosu na zebraniu. $Z$ zebrania redaguje się protokół podpisany przez przewodniczącego i sekretarza oraz ewentualnie przez skrutatorów ${ }^{86}$. Przedmiotem obrad jest sprawozdanie przewodniczącego i skarbnika, budżet, bilans i kosztorys, kierunki i dyrektywy ogólne Stowarzyszenia. Rada Zarządzająca i członkowie wybierają kolegium rewizorów. Uchwały są przyjmowane zwykłą większością wyborców ${ }^{87}$.

\footnotetext{
${ }^{82}$ Tamże, art. 19-20.

${ }^{83}$ Tamże, art. 21-22.

84 Tamże, art. 23.

85 Tamże, art. 10.

86 Tamże, art. 12.

${ }^{87}$ Tamże, art. 10 .
} 
W zebraniu powszechnym (walnym) mają prawo brać udział członkowie honorowi, jak i zwyczajni oraz sympatycy w zależności od opłacanych składek rocznych na Stowarzyszenie ${ }^{88}$.

Redaktorzy Estatutos de la Asociación de Bibliotecarios de la Iglesia en España przypominają, że organami Stowarzyszenia Bibliotekarzy Kościelnych w Hiszpanii są Walne Zgromadzenie członków i Zarząd ${ }^{89}$. Stowarzyszenie kierowane i zarządzane jest przez Zarząd złożony z przewodniczącego, wiceprzewodniczącego, sekretarza, skarbnika i trzech członków. W kwestii wyboru członków Zarządu statut postanawia, że przewodniczący jest powoływany przez Komisję Stałą Konferencji Biskupiej Hiszpanii po przedstawieniu trzech kandydatów wybranych przez ogólne zgromadzenie Stowarzyszenia. Pozostałe urzędy Zarządu są wybierane przez członków zwyczajnych obecnych na Walnym Zgromadzeniu. Desygnowanie trzech kandydatów i wybory członków Zarządu dokonują się bezwzględną większością w pierwszym i drugim głosowaniu. Jeśli nie zostaną wybrani, wybiera się między tymi dwoma kandydatami, którzy uzyskali największą liczbę głosów w drugim głosowaniu, uważając za wybranego tego, który otrzymał większą liczbę głosów w trzecim głosowaniu, a w przypadku równej liczby głosów, najstarszego ze Stowarzyszenia. Czas sprawowania wszystkich funkcji w Zarządzie wynosi cztery lata. Z wyjątkiem przewodniczącego pozostałych sześć stanowisk odnawia się o połowę, co dwa lata, po ukończeniu pierwszej kadencji. Kolejność odnowienia określa zgromadzenie. Ustępujący członkowie Zarządu będą mogli być powtórnie wybrani na drugie i trzecie czterolecie ${ }^{90}$.

Zgodnie ze statutem Asociación de Bibliotecarios de la Iglesia en España Zarząd zbiera się przynajmniej dwa razy w roku oraz jeżeli dobro Stowarzyszenia tego wymaga lub zgodnie z decyzją przewodniczącego, lub na pisemny wniosek większości jego członków. Zawiadomienie o zebraniu musi mieć formę pisemną i być doręczone z wyprzedzeniem przynajmniej ośmiu dni roboczych. Decyzje Zarządu podejmowane są bezwzględną większością głosów obecnych członków. W przypadku równej liczby głosów będzie mógł zadecydować swoim głosem przewodniczący ${ }^{11}$.

Według Estatutos de la Asociación de Bibliotecarios de la Iglesia en España Zarząd ma następujące kompetencje: kierowanie i promowanie działalności Stowarzyszenia; wdrażanie postanowień zatwierdzonych przez Walne Zgromadzenie (stąd posiada pełne uprawnienia do działania w imieniu Stowarzyszenia), zarządzanie majątkiem Stowarzyszenia w granicach rocznego budżetu zatwierdzonego przez zgromadzenie (w celu dokonania zbycia majątku i czynności administracyjnych, które nie są przewidziane w budżecie rocznym i pociągają za sobą ryzyko szkód ekonomicznych w majątku Stowarzyszenia, Zarząd Stowarzyszenia potrzebuje zgody Walnego Zgromadzenia); zdawanie rocznego sprawozdania ze swojego Zarządu Konferencji Biskupiej; przed przedstawieniem sprawozdania fi-

\footnotetext{
${ }^{88}$ Tamże, art. 11.

${ }^{89}$ Estatutos de la Asociación, art. 15.

90 Tamże, art. 20-22.

91 Tamże, art. 23.
} 
nansowego Walnemu Zgromadzeniu Zarząd ma zapoznać się z bilansem i budżetem; ustalanie daty Walnego Zgromadzenia i porządku obrad ${ }^{92}$.

Gdy chodzi o funkcje i kompetencje przewodniczącego wiceprzewodniczącego Stowarzyszenia Bibliotekarzy Kościelnych w Hiszpanii, są one następujące: legalne reprezentowanie Stowarzyszenia; podejmowanie decyzji o zwołaniu Walnych Zgromadzeń i spotkań Zarządu; podpisywanie akt razem z sekretarzem; właściwe zarządzanie dobrami Stowarzyszenia, do czego zgromadzenie ogólne albo - w przypadku jego braku - Zarząd poprzednio go do tego upoważniły; ustalanie wydatków i dokonywanie płatności; udzielanie pełnomocnictw dla spraw postanowionych przez zgromadzenie ogólne albo Zarząd ${ }^{93}$.

W Stowarzyszeniu Bibliotekarzy Kościelnych w Hiszpanii skarbnik ma następujące kompetencje: prowadzenie księgowości Stowarzyszenia; przygotowanie bilansu rocznego i budżetu Stowarzyszenia oraz przedstawienie go Walnemu Zgromadzeniu do zatwierdzenia, po rozpatrzeniu przez Zarząd; wykonywanie aktów administracji zwyczajnej, którą mu zleca Zarząd z odpowiadającą możliwością dysponowania środkami Stowarzyszenia; prowadzenie na bieżąco inwentaryzacji majątku Stowarzyszenia ${ }^{94}$.

Sekretarz Asociación de Bibliotecarios de la Iglesia en España posiada następujące kompetencje: zwoływanie, z upoważnienia prezesa Zarządu posiedzeń Zarządu i Walnego Zgromadzenia; zbieranie propozycji członków w celu przygotowania Walnego Zgromadzenia; sporządzanie protokołów z posiedzeń Zarządu i przekazywanie ich wszystkim członkom Zarządu; przesyłanie wszystkim członkom zgromadzenia ogólnego protokołu z ostatniej sesji i umieszczenie go w księdze protokołów Zarządu i zgromadzenia wraz z podpisem prezesa; staranne prowadzenie: ewidencji członków wraz z rejestracją i odwołaniami, własnego archiwum Stowarzyszenia oraz prowadzenie korespondencji i wydawanie zaświadczeń oraz kopii posiadanej dokumentacji ${ }^{95}$.

\section{Majątek Stowarzyszeń Bibliotek Kościelnych Polsce, Włoszech i Hiszpanii}

Zgodnie z kan. 319 § 1 stowarzyszenie publiczne, erygowane zgodnie z przepisami prawa (a takim są omawiane Stowarzyszenia Bibliotekarzy Kościelnych), jeśli czego innego nie zastrzeżono, zarządza posiadanymi dobrami zgodnie z postanowieniami statutów, pod zwierzchnim kierownictwem władzy kościelnej, której też należy każdego roku składać sprawozdania z zarządzania.

Według Statutu Federacji Bibliotek Kościelnych „Fides” majątek federacji stanowią: 1) składki członkowskie; 2) darowizny, spadki, zapisy, dotacje przekazywane na zasadach obowiązujących ogół podmiotów nienależących do sektora finansów publicznych; 3) dochody z odpłatnej działalności statutowej Federacji, w tym wydawniczej; 4) inne wpływy związane z działalnością statutową; 5) komputery, serwery, urządzenia do digitalizacji i inne dobra ruchome zakupione przez

\footnotetext{
92 Tamże, art. 24.

93 Tamże, art. 25.

${ }^{94}$ Tamże, art. 26.

${ }^{95}$ Estatutos de la Asociación, art. 27.
} 
Federację i służące jej funkcjonowaniu. Decyzje w sprawie nabywania, zbywania i obciążania majątku Federacji podejmuje Zarząd. Uszczuplenie majątku Federacji ponad kwotę równą sumie rocznych składek członkowskich wszystkich członków Federacji wymaga uprzedniej uchwały Walnego Zgromadzenia. Nie dotyczy to projektów w ramach umów o dofinansowanie. Do zawierania umów i składania innych oświadczeń woli w sprawach majątkowych Federacji uprawniony jest Przewodniczący Zarządu ${ }^{96}$.

Z kolei zgodnie ze Estatutos de la Asociación de Bibliotecarios de la Iglesia en España na majątek Stowarzyszenia składaja się: roczne składki członkowskie, jak i dochody z publikacji, darowizny, zapisy lub udziały przekazywane Stowarzyszeniu przez osoby fizyczne lub instytucje prywatne czy podmioty publiczne, które są przeznaczane na wspólne i właściwe wydatki Stowarzyszenia. Redaktorzy statutu dodają, że zarządzanie majątkiem Stowarzyszenia odbywa się zgodnie z normami statutu i przepisami prawa kanonicznego ${ }^{97}$ oraz, że w przypadku rozwiązania Stowarzyszenia jego majątek zostanie wykorzystany do celów określonych przez większość członków Walnego Zgromadzenia zgodnie z Kodeksem Prawa Kanonicznego ${ }^{98}$.

Natomiast majątek Stowarzyszenie Bibliotekarzy Kościelnych Włoch stanowią dobra ruchome i nieruchome będące własnością Stowarzyszenia; ewentualne nadwyżki budżetowe, pożyczek, darowizny i zapisy. Natomiast na dochody Stowarzyszenia składają się: składki członkowskie, zyski pochodzące z organizacji imprez lub uczestnictwa w nich oraz z publikacji ${ }^{99}$. Prawodawca statutowy dodaje, że rok obrachunkowy kończy się 31 grudnia każdego roku. Do końca każdego roku budżetowego Zarząd sporządza budżet na następny rok budżetowy; w terminie 90 dni od zakończenia każdego roku budżetowego sporządza ostateczny bilans końcowy ${ }^{100}$.

Należy dodać, że według Statutu „Fides”, wszelkie zmiany statutu wymienionej Federacji wymagają uchwały Walnego Zgromadzenia podjętej większością co najmniej $2 / 3$ głosów - w pierwszym terminie, przy obecności co najmniej połowy ogólnej liczby członków zwyczajnych lub ich pełnomocników, a w drugim terminie bez względu na liczbę obecnych. Prawo wnoszenia propozycji zmian w Statucie przysługuje wyłącznie członkom zwyczajnym Federacji. Zmiana Statutu staje się prawomocna po zatwierdzeniu przez Konferencję Episkopatu Polski zgodnie z kan. $314 \mathrm{KPK}^{101}$.

W Statuto dell'Associazione dei Bibliotecari Ecclesiastici Italiani stwierdza się, że o wszelkich zmianach w Statucie rozstrzyga Walne Zgromadzenie zwołane w tym celu, większością dwóch trzecich obecnych, przy czym co najmniej jedna

\footnotetext{
${ }^{96}$ Statut ,Fides”, art. 40-42.

${ }^{97}$ Estatutos de la Asociación, art. 29-30.

${ }^{98}$ Tamże, art. 33.

${ }^{99}$ Statuto dell'Associazione, art. 4.

${ }^{100}$ Tamże, art. 5.

${ }^{101}$ Statut ,Fides”, art. 43-45.
} 
trzecia członków musi być obecna na Walnym Zgromadzeniu. Zmiany w Statucie wchodzą w życie po zatwierdzeniu przez Konferencję Episkopatu Włoch ${ }^{102}$.

Estatutos de la Asociación de Bibliotecarios de la Iglesia en España stanowi: wszelkie zmiany niniejszego statutu wymagają zatwierdzenia przez Walne Zgromadzenie bezwzględną większością głosów wszystkich członków oraz zatwierdzenia przez Konferencję Biskupów ${ }^{103}$.

Rozwiązanie Federacji, to zgodnie ze Statutem „Fides” może zostać ona zlikwidowana przez Konferencję Episkopatu Polski z jej inicjatywy lub z uwzględnieniem uchwały Walnego Zgromadzenia o woli rozwiązania Federacji, powziętej w obecności co najmniej połowy ogólnej liczby członków zwyczajnych lub ich pełnomocników, większością co najmniej $2 / 3$ głosów. W razie rozwiązania $\mathrm{Fe}-$ deracji jej majątek, zarówno nieruchomy, jak i ruchomy, przechodzi na własność Konferencji Episkopatu Polski ${ }^{104}$

Statuto dell'Associazione dei Bibliotecari Ecclesiastici Italiani stanowi, że o rozwiązaniu Stowarzyszenia decyduje Walne Zgromadzenie większością dwóch trzecich głosów obecnych, przy czym co najmniej jedna trzecia członków ma być obecna na posiedzeniu. Walne Zgromadzenie członków powołuje jednego lub więcej likwidatorów, określa ich uprawnienia i decyduje o przeznaczeniu mająt$\mathrm{ku}^{105}$, natomiast rozwiązanie Asociación de Bibliotecarios de la Iglesia en España należy do Hiszpańskiej Konferencji Episkopatu: a) z własnej inicjatywy, w przypadku zaistnienia poważnych przyczyn, po wysłuchaniu Prezesa Zarządu i pozostałych członków Zarządu; b) na wniosek Stowarzyszenia, po uzgodnieniu przez jego członków na Walnym Zgromadzeniu większością dwóch trzecich obecnych. W przypadku rozwiązania majątek Stowarzyszenia zostanie wykorzystany w celach określonych większością głosów Walnego Zgromadzenia zgodnie z Kodeksem Prawa Kanonicznego. Jeśli z jakiegoś powodu decyzja ta nie zostanie podjęta, dobra zostaną przeniesione na Konferencję Episkopatu Hiszpanii. W każdym przypadku należy zachować wolę darczyńców ${ }^{106}$.

\section{Wnioski}

1. Statuty powinny informować przez kogo zostało erygowane dane stowarzyszenie bibliotek kościelnych, kto i kiedy zatwierdził te statuty, czy dane stowarzyszenie bibliotek kościelnych działa na mocy porozumienia, zgodnie z prawem państwowym, czy jest ono organizacją prawa publicznego czy prywatnego, czy obowiązuje je prawo o stowarzyszeniach.

2. Statuty winny zawierać odniesienia do odpowiednich przepisów prawa kanonicznego i prawomocnego prawa państwowego.

3. Przepisy statutów stowarzyszeń bibliotek kościelnych powinny jasno sytuować te stowarzyszenia w szerokim kontekście państwowego i międzynarodowego

\footnotetext{
${ }^{102}$ Statuto dell'Associazione, art. 24.

${ }^{103}$ Estatutos de la Asociación, art. 31.

${ }^{104}$ Statut ,Fides”, art. 46.

${ }^{105}$ Statuto dell'Associazione, art. 5.

${ }^{106}$ Estatutos de la Asociación, art. 32-33.
} 
systemu bibliotecznego, sprzyjając relacjom i konstruktywnemu dialogowi zarówno z państwowymi, jak i z lokalnymi organami ochrony i promocji oraz $\mathrm{z}$ instytucjami religijnymi i kulturalnymi.

4. Stowarzyszenie bibliotekarzy kościelnych danego kraju winno być stowarzyszeniem publicznym, tzn. erygowanym przez miejscową konferencję episkopatu, co powinno być uwidocznione w statucie.

5. W statucie należy się odwołać do określonych ustaleń konkordatu, jeśli taki obowiązuje w danym państwie.

6. Statut winien uwzględniać czytelny i wyraźny podział członkostwa w stowarzyszeniu: członkowie zwyczajni, członkowie wspierający i członkowie honorowi.

7. Statuty winny eksponować ewangelizacyjne cele stowarzyszenie bibliotek kościelnych.

\section{REFERENCES / BIBLIOGRAFIA}

\section{Źródla}

Codex Iuris Canonici. Auctoritate Ioannis Pauli PP. II promulgatus. Kodeks Prawa Kanonicznego, przekład polski zatwierdzony przez Konferencję Episkopatu, Poznań 1984.

Pontificia Commissione per i Beni Culturali della Chiesa, Lettera circolare Le biblioteche ecclesiastiche nella missione della Chiesa (19 marzo 1994), Enchiridion dei Beni Culturali della Chiesa. Documenti ufficiali della Pontificia Commissione per i Beni Culturali della Chiesa, Bologna 2002, s. 201-219, tekst polski: „Fides. Biuletyn Bibliotek Kościelnych", 1-2 (1996) s. 31-46.

Statut Federacji Bibliotek Kościelnych ,Fides” (29 kwietnia 2000), „Fides Biuletyn Bibliotek Kościelnych”, 10-11 (2000) nr 1-2, s. 30-40.

Statut Federacji Bibliotek Kościelnych ,Fides” (13 października 2017), http://www.fides. org.pl/pdf/Statut_nowy.pdf, (dostęp: 20.11.2019).

Statut Federacji Bibliotek Kościelnych ,Fides” (18 marca 1995), „Fides - Biuletyn Bibliotek Kościelnych", 1 (1995), s. 9-16.

Estatutos de la Asociación de Bibliotecarios de la Iglesia en España para la Defensa, conservación y difusión de su Patrimonio Bibliográfico (22 noviembre 2007), „Patrimonio cultural Documentación, estudios, información”, 46 (2007) s. 107-114.

Statuto dell'Associazione dei Bibliotecari Ecclesiastici Italiani (2 aprile 2003), „Bollettino di informazione", 23 (2003) fasc.1, s. 4-8.

\section{Opracowania}

Komentarz do Kodeksu Prawa Kanonicznego. T. 2. Ks. II (1). Lud Boży, red. J. Krukowski, Poznań 2005. 


\title{
THE ASSOCIATION OF CHURCH LIBRARIES IN POLAND, ITALY AND SPAIN IN THE VIEW OF THEIR STATUTES
}

\begin{abstract}
The aim of this article is presenting the issue of Association of Church Libraries in the view of chosen statutes in terms of canonic aspect. In its first part the issue of nature, aims and modes of action of the Association of Church Libraries are presented. In the second part the inner organisation od the Association is depicted, the third part is devoted to authorities, while the forth one treats about the wealt of the Association of Church Libraries.
\end{abstract}

Keywords: library; statute; books; association of church libraries; patrimony property; church library

Translated by Maciej Łoś 